\title{
Characterization of Cucurbit Powdery Mildews by Morphological and Microscopic Studies
}

\author{
S. Priyanka ${ }^{1}$, L. Rajendran ${ }^{1}$, R. Anandham ${ }^{2}$ and T. Raguchander ${ }^{1 *}$ \\ ${ }^{1}$ Department of Plant Pathology, ${ }^{2}$ Department of Agricultural Microbiology \\ Tamil Nadu Agricultural University, Coimbatore - 641 003, India \\ *Corresponding author
}

\begin{tabular}{l} 
K e y w o r d s \\
$\begin{array}{l}\text { Cucurbits, diseases, } \\
\text { percent disease } \\
\text { index (PDI) and } \\
\text { powdery mildew }\end{array}$ \\
\hline Article Info \\
$\begin{array}{l}\text { Accepted: } \\
\text { 05 June } 2020 \\
\text { Available Online: } \\
\text { 10 July } 2020\end{array}$ \\
\hline
\end{tabular}

\section{Introduction}

Cucurbits are economically important crops that play a major role in vegetable production. Among the different production constraints, the disease namely powdery mildew is the most common and serious fungal disease that arises both in field and greenhouse conditions all over the world. The disease is caused by two obligate biotrophs such as Sphaerotheca fuliginea (Syn. Podosphaera xanthii) and Erysiphe cichoracearum (Syn. Golovinomyces cichoracearum) (Vakalounakis et al., 1994; Kristkova et al., 2000). The disease causes reduction in plant growth, premature defoliation and as a result, both yield and quality of fruits gets reduced that ultimately leads to major production problem (Lebeda $e t$ al., 2010).

Podosphaera xanthii occurs mostly in warmer months (Rur et al., 2017) whereas Erysiphe cichoracearum in cooler spring and in early summer months (Aguiar et al., 2012). 
The two obligate biotrophs produce indistinguishable symptoms but can be easily distinguished by light microscopic studies (Braun et al., 2002). The difference between the two species Podosphaera xanthii and Erysiphe cichoracearum can be made according to morphology of the conidia, the presence or absence of fibrosin bodies in interior of the conidia and the morphology of the germinative tube of conidia (Garcia et al., 2010).

Therefore, the objective of the study is to identify and characterize the powdery mildew isolates from various hosts of cucurbit crops which will provide explicit information about the causal agents. This study also evaluates disease severity caused by both pathogens.

\section{Materials and Methods}

\section{Survey with GPS coordinates}

During 2019-20, powdery mildew infected leaf samples from various hosts of cucurbits were collected by conducting survey in Coimbatore and Dindigal districts of Tamil Nadu, India. The samples were collected from various locations such as Poosaripalayam, Sattakalpudhur, PN Pudhur, Thondamuthur, Kinathukadavu, Vettaikaranpudhur, Arasampalayam of Coimbatore district and Sembatti, Paraipatti, Vellodu of Dindugal district where cucurbits are largely cultivated. During the survey, observations on disease intensity, stage and variety of the crop and GPS coordinates of the locations were recorded.

\section{Powdery mildew and its severity}

The disease intensity (percentage of leaf area infected) was assessed using disease score chart which includes 0-9 scales given by Jamadar and Desai (1997). The disease score was converted to Percent disease Index (PDI) which was described by Mc Kinney's (1923). Percent Disease Index was calculated by randomly selecting fifteen leaves and worked out using the following formula

$$
\text { PDI }=\frac{\text { Sum of all numerical ratings }}{\text { Total number of leaves observed }} \times \frac{100}{-} \text { Maximum disease grade }
$$

\section{Microscopic studies}

The morphological characters of the causal agents such as presence or absence of conspicuous fibrosin bodies, the dimensions of conidia and conidiophore, shape of conidia, type of mycelium and appresoria were characterized by means of taking observation under light microscope.

The image was captured using image analyser. The conidial numbers (25 conidia per sample) were counted and out of these, the length and width of ten conidia was measured. To study better structural aspects, the conidia and conidiophores has been stained with cotton blue in lactophenol.

\section{Pathogenicity study}

To prove the pathogenicity of causal agents, Koch's postulates have been established. Pathogenicity assay was proved for powdery mildew of cucurbits caused by two causal agents Podosphaera xanthii and Erysiphe cichoracearum in glasshouse and laboratory conditions.

In glasshouse, cucumber (Japanese Long green) and bitter gourd (CO 1) have been raised under controlled conditions in earthen pots containing the mixture of red soil, sand and farm yard manure at the ratio of $2: 1: 1$. Diseased samples showing typical symptoms of powdery mildew caused by Podosphaera xanthii in cucumber and Erysiphe cichoracearum in bitter gourd were collected. 
The conidia of Podosphaera xanthii was inoculated in 30 days old cucumber plant and the conidia of Erysiphe cichoracearum in 30 days old bitter gourd plant by brushing the conidia onto the leaf by small camel's brush and control plant was maintained for each without inoculation of conidia.

The plants were covered with polythene covers to maintain humidity for 24 to 48 hours. In laboratory conditions, healthy detached leaves of cucumber and bitter gourd were collected and surface sterilized with $70 \%$ ethanol and then washed three times thoroughly with sterile distilled water. The leaves were placed in petri dishes with three layers of moistened sterile filter paper.

The leaves of cucumber were inoculated with sporulating colonies of Podosphaera xanthii onto the sites of leaf by slight brushing of conidia. Likewise, the leaves of bitter gourd inoculated with Erysiphe cichoracearum. The petriplates were wrapped with parafilm and incubated at $25^{\circ} \mathrm{C}$ with 16 hours of photoperiod. An observation on the growth of powdery patches on leaves is recorded at regular intervals.

\section{Statistical analysis}

The microscopic study has been repeated for three times to capture the images and conidia length, breadth were measured. The glasshouse study for the pathogenicity has been carried out by using completely randomized design (CRD). Statistical analysis were done using IRRISTAT version 92 developed by the International Rice Research Institute Biometrics unit, the Philippines (Gomez and Gomez, 1984) and the percentage values of the disease index were arcsine transformed. Data were subjected to ANOVA at significant level $(\mathrm{P}<0.05)$ and means were compared by Duncan's multiple range test (DMRT).

\section{Results and Discussion}

\section{Survey and disease severity assessment}

The survey was conducted in various locations of Coimbatore and Dindugal district during the year 2019 - 2020. The cucurbits powdery mildew showing symptoms typically on both upper and lower surface of leaves and later stage on petioles stems and fruits were observed (Fig.1).

The results showed that the severity for the powdery mildew of cucurbits ranged from 30.25 to 71.24 PDI. Maximum disease severity was noticed in ash gourd (71.24 PDI) collected from PN Pudur followed by snake gourd (69.12 PDI) collected from Arasampalayam of Coimbatore district.

The minimum disease severity was noticed in watermelon (30.25 PDI) collected from Korapalayam of Dindugal district (Table 1). Pathogenecity spectrum of disease is similar to other states in India. In a study conducted on cucurbits indicated that infection in plants in one or the other locality comprising of these districts were distinct.

Among the cucurbits, ash gourd was most severely affected. The species responsible for the disease in the state were identified as Podoshaera xanthii and Golovinomyces cichoracearum (Khan and Khan., 1996; Gupta et al., 2012;). The incidence and disease severity of powdery mildews in cucumber, bhendi and pea crops varied in different locations across the state which is similar to this present investigation (Parthasarathy et al., 2017; Rajalakshmi et al., 2016; Parameshwar Naik et al., 2018).

\section{Morphological and microscopic studies}

During the survey, twenty powdery mildew infected samples from major cucurbit crops 
have been collected. The morphological examinations of the collected samples from various hosts of cucurbits were done using light microscope. With the help of image analyser, the images have been captured and the results revealed that both the causal organism Erysiphe cichoracearum and Podosphaera xanthii was responsible for cucurbit powdery mildew. The two causal organisms have been distinguished by the presence of fibrosin bodies. Podosphaera xanthii which causes powdery mildew in cucumber contains ovoid conidia with long refractile fibrosin bodies, with discoid fibrosin bodies in snake gourd and found to be absent in Erysiphe cichoracearum.

The conidial mean length of Podosphaera xanthii ranges from 30.51 to $40.88 \mu \mathrm{m}$ and for E. cichoracearum it ranges from 32.08 to $46.87 \mu \mathrm{m}$ whereas the conidial mean width of Podosphaera xanthii ranges from 21.28 to $29.65 \mu \mathrm{m}$ and for E. cichoracearum it ranges from 16.52 to $29.65 \mu \mathrm{m}$. Mycelium is hyaline with septations and condiophore with catenate type of conidia was observed (Table 2).

Similar observation is reported in $P$. xanthii which produced tubular germ tube with indistinct appresoria whereas Erysiphe cichoracearum produced simple apical germ tube with lobed appresoria (Fig.2). Fibriform substances was also present in the conidiophores of $P$. xanthii whereas it is absent in E. cichoracearum. The two obligate biotrophic polyphagous fungi cannot be distinguished visually but can be differentiated morphologically by microscopic studies (Vakalounakis et al., 1994). The difference between conidial length and width ratio of the two causal agents was described by various researchers (Frolov., 1996; Rankovic., 2003). The dimensions of conidia of chilli were measured in chilli powdery mildew which is similar to present study (Bademiyya et al., 2019)

\section{Pathogenecity study}

In pathogenecity assay, Podosphaera xanthii took initial infection after 4 days of inoculation whereas Erysiphe cichoracearum after 5 days of inoculation under glasshouse conditions favoured by high relative humidity and dry conditions for the development of infection. The disease looks severe after 10 days of inoculation (Fig 3 and Fig.4). The maximum of 25 and minimum of 10 conidia were observed by taking sections of artificially inoculated leaves and conidia of both causal agents were noticed similar to the conidia inoculated respectively.

Under laboratory coniditions, half of the leaf area have been covered with mildew colonies after four to seven days of inoculation and the condial characters were observed same as above for both causal agents in detached leaf assay. In accordance with Koch's postulates, healthy cucurbit plants showed typical disease symptoms whereas control plant showed no disease symptoms (Cohen et al., 1996).

Rajalakshmi et al., (2016) described about the pathogenecity test of bhendi and pea powdery mildew under glasshouse conditions and Parthasarathy et al., (2018) described about the detached leaf assay of pea powdery mildew under glasshouse conditions. Similarly, Lovepreet Kaur (2019) also proved the pathogenicity test in case of mango powdery mildew.

A. Conidiophore of Podosphaera xanthii with fibriform substances B. Conidia of Podosphaera xanthii C. Conidia of P.xanthii with long, thin fibrosin bodies D. Conidia of $P$. xanthii with discoid fibrosin bodies $\mathrm{E}$. Conidiophore of E.cichoracearum with catenate conidia. F. Erect conidiophore and conidia of Erysiphe cichoracearum stained with lactophenol G. Conidia of $E$. cichoracearum without fibrosin bodies $\mathrm{H}$. 
Table.1 Survey and assessment of powdery mildew in major cucurbit crops

\begin{tabular}{|c|c|c|c|c|c|c|c|c|c|}
\hline \multirow[t]{2}{*}{ S.No } & \multirow[t]{2}{*}{ Host Plant } & \multirow[t]{2}{*}{ Cultivar } & \multirow{2}{*}{$\begin{array}{l}\text { Stage of the } \\
\text { crop }\end{array}$} & \multirow[t]{2}{*}{ Season } & \multicolumn{2}{|c|}{ Location } & \multicolumn{2}{|c|}{ GPS Coordinates } & \multirow{2}{*}{$\begin{array}{l}\text { Mean PDI of } \\
\text { powdery } \\
\text { mildew* }\end{array}$} \\
\hline & & & & & District & Village & Latitide & Longitude & \\
\hline 1. & Snake Gourd & $\mathrm{CO} 2$ & Flowering & Kharif & Coimbatore & Poosaripalyam & $11.062^{\circ} \mathrm{N}$ & $76.933^{\circ} \mathrm{E}$ & $\begin{array}{l}59.12^{\mathrm{e}} \\
(50.25)\end{array}$ \\
\hline 2. & Snake Gourd & $\mathrm{CSgH} 1$ & Fruit Formation & Kharif & Dindugal & Sembatti & $10.282^{\circ} \mathrm{N}$ & $77.872^{\circ} \mathrm{E}$ & $\begin{array}{l}35.63^{\circ} \\
(36.65)\end{array}$ \\
\hline 3. & Snake Gourd & Kaumudi & Fruit Formation & Kharif & Dindugal & Paraipatti & $10.321^{\circ} \mathrm{N}$ & $77.856^{\circ} \mathrm{E}$ & $\begin{array}{l}38.16^{\mathrm{m}} \\
(38.15)\end{array}$ \\
\hline 4. & Bitter Gourd & Palee & Fruit Formation & Kharif & Dindugal & Vellodu & $10.306^{\circ} \mathrm{N}$ & $77.954^{\circ} \mathrm{E}$ & $\begin{array}{c}32.28^{\mathrm{p}} \\
(34.62)\end{array}$ \\
\hline 5. & Bitter Gourd & Arya & Flowering & Rabi & Coimbatore & Sattakal Pudhur & $10.819^{\circ} \mathrm{N}$ & $76.926^{\circ} \mathrm{E}$ & $\begin{array}{l}31.64^{\mathrm{pq}} \\
(34.23)\end{array}$ \\
\hline 6. & Water melon & Local & Maturity & Kharif & Dindugal & Korapalayam & $10.948^{\circ} \mathrm{N}$ & $77.325^{\circ} \mathrm{E}$ & $\begin{array}{c}30.25^{q} \\
(33.37)\end{array}$ \\
\hline 7. & Ridge gourd & PKM 1 & Fruit Formation & Kharif & Dindugal & Paraipatti & $10.321^{\circ} \mathrm{N}$ & $77.856^{\circ} \mathrm{E}$ & $\begin{array}{l}38.04^{\mathrm{mn}} \\
(38.08)\end{array}$ \\
\hline 8. & Ash Gourd & $\mathrm{CO} 2$ & Fruit Formation & Rabi & Coimbatore & PN Pudhur & $11.006^{\circ} \mathrm{N}$ & $76.930^{\circ} \mathrm{E}$ & $\begin{array}{l}71.24^{a} \\
(57.56)\end{array}$ \\
\hline 9. & Cucumber & $\begin{array}{c}\text { Japanese Long } \\
\text { green }\end{array}$ & Maturity & Rabi & Coimbatore & PN Pudhur & $11.006^{\circ} \mathrm{N}$ & $76.930^{\circ} \mathrm{E}$ & $\begin{array}{l}55.32^{\text {gh }} \\
(48.05)\end{array}$ \\
\hline 10. & Pumpkin & Arjuna & Maturity & Kharif & Coimbatore & Thondamuthur & $11.005^{\circ} \mathrm{N}$ & $76.823^{\circ} \mathrm{E}$ & $\begin{array}{l}54.13^{\text {hi }} \\
(47.37)\end{array}$ \\
\hline 11. & Snake Gourd & $\mathrm{CO} 2$ & Maturity & Rabi & Coimbatore & Kinathukadavu & $10.817^{\circ} \mathrm{N}$ & $77.018^{\circ} \mathrm{E}$ & $\begin{array}{l}58.01^{\text {ef }} \\
(49.60)\end{array}$ \\
\hline 12. & Pumpkin & $\mathrm{CO} 2$ & Maturity & Rabi & Coimbatore & Kinathukadavu & $10.817^{\circ} \mathrm{N}$ & $77.018^{\circ} \mathrm{E}$ & $\begin{array}{l}51.63^{\mathrm{j}} \\
(45.93)\end{array}$ \\
\hline 13. & Bottle Gourd & PKM 1 & Fruit Formation & Rabi & Coimbatore & Poosaripalayam & $11.062^{\circ} \mathrm{N}$ & $76.933^{\circ} \mathrm{E}$ & $\begin{array}{l}58.04^{\text {ef }} \\
(49.62)\end{array}$ \\
\hline 14. & Snake Gourd & Local & Fruit Formation & Rabi & Coimbatore & Vettaikaranpudhur & $10.603^{\circ} \mathrm{N}$ & $76.902^{\circ} \mathrm{E}$ & $\begin{array}{l}49.64^{\mathrm{k}} \\
(44.79)\end{array}$ \\
\hline 15. & Pumpkin & Local & Maturity & Rabi & Coimbatore & Vettaikaranpudhur & $10.603^{\circ} \mathrm{N}$ & $76.902^{\circ} \mathrm{E}$ & $\begin{array}{l}56.51^{\mathrm{fg}} \\
(48.74)\end{array}$ \\
\hline 16. & Snake gourd & Local & Maturity & Rabi & Coimbatore & Arasampalayam & $10.657^{\circ} \mathrm{N}$ & $77.010^{\circ} \mathrm{E}$ & $\begin{array}{l}69.12^{\mathrm{b}} \\
(56.24)\end{array}$ \\
\hline 17. & Ridge Gourd & Local & Vegetative & Rabi & Coimbatore & Arasampalayam & $11.564^{\circ} \mathrm{N}$ & $79.902^{\circ} \mathrm{E}$ & $\begin{array}{l}59.57^{\mathrm{d}} \\
(50.52)\end{array}$ \\
\hline 18. & Pumpkin & Local & Fruit formation & Rabi & Coimbatore & Arasampalayam & $10.654^{\circ} \mathrm{N}$ & $77.010^{\circ} \mathrm{E}$ & $\begin{array}{c}46.31^{1} \\
(42.88)\end{array}$ \\
\hline 19. & Bitter Gourd & $\mathrm{CO} 1$ & Vegetative Stage & Rabi & Coimbatore & PN Pudhur & $11.006^{\circ} \mathrm{N}$ & $76.930^{\circ} \mathrm{E}$ & $\begin{array}{l}61.21^{\mathrm{c}} \\
(51.48)\end{array}$ \\
\hline
\end{tabular}

PDI - Percent Disease Index, *Values are mean of three replicates

Values in parentheses are arcsine transformed values

In a column, means followed by a common letter are not significantly different at the 5\% level by DMRT 
Table.2 Microscopic studies of causal agents of various hosts of cucurbits powdery mildew

\begin{tabular}{|c|c|c|c|c|c|c|}
\hline \multirow[t]{2}{*}{ Host } & \multirow{2}{*}{$\begin{array}{c}\text { Host } \\
\text { organism }\end{array}$} & \multicolumn{2}{|c|}{ Conidia* } & \multirow[t]{2}{*}{ Conidial shape } & \multirow[t]{2}{*}{ Mycelium } & \multirow{2}{*}{$\begin{array}{c}\text { Types of } \\
\text { Appresoria }\end{array}$} \\
\hline & & Length $(\mu \mathrm{m})$ & Width $(\mu \mathrm{m})$ & & & \\
\hline $\begin{array}{l}\text { Snake } \\
\text { gourd }\end{array}$ & $\begin{array}{l}\text { Podosphaera } \\
\text { xanthii }\end{array}$ & 30.514 & 21.283 & $\begin{array}{c}\text { Ovoid with } \\
\text { discoid fibrosin } \\
\text { bodies }\end{array}$ & $\begin{array}{c}\text { Hyaline, } \\
\text { Septate }\end{array}$ & Indistinct \\
\hline $\begin{array}{l}\text { Bitter } \\
\text { gourd }\end{array}$ & $\begin{array}{c}\text { Erysiphe } \\
\text { cichoracearum }\end{array}$ & 44.053 & 21.012 & $\begin{array}{c}\text { Cylindrical to } \\
\text { ovoid }\end{array}$ & $\begin{array}{l}\text { Hyaline, } \\
\text { Septate }\end{array}$ & Lobed \\
\hline $\begin{array}{l}\text { Ridge } \\
\text { gourd }\end{array}$ & $\begin{array}{c}\text { Erysiphe } \\
\text { cichoracearum }\end{array}$ & 44.418 & 20.596 & $\begin{array}{c}\text { Cylindrical to } \\
\text { ovoid }\end{array}$ & $\begin{array}{l}\text { Hyaline, } \\
\text { Septate }\end{array}$ & Lobed \\
\hline Ash gourd & $\begin{array}{c}\text { Erysiphe } \\
\text { cichoracearum }\end{array}$ & 46.871 & 16.525 & Cylindrical & $\begin{array}{c}\text { Hyaline, } \\
\text { Septate }\end{array}$ & Lobed \\
\hline $\begin{array}{l}\text { Bottle } \\
\text { gourd }\end{array}$ & $\begin{array}{c}\text { Erysiphe } \\
\text { cichoracearum }\end{array}$ & 36.277 & 26.007 & $\begin{array}{c}\text { Cylindrical to } \\
\text { ovoid }\end{array}$ & $\begin{array}{c}\text { Hyaline, } \\
\text { Septate }\end{array}$ & Lobed \\
\hline Pumpkin & $\begin{array}{c}\text { Erysiphe } \\
\text { cichoracearum }\end{array}$ & 32.080 & 23.686 & $\begin{array}{c}\text { Cylindrical to } \\
\text { ovoid }\end{array}$ & $\begin{array}{c}\text { Hyaline, } \\
\text { Septate }\end{array}$ & Lobed \\
\hline Cucumber & $\begin{array}{c}\text { Podosphaera } \\
\text { xanthii }\end{array}$ & 40.887 & 29.656 & $\begin{array}{l}\text { Ovoid with } \\
\text { long refractile } \\
\text { fibrosin bodies }\end{array}$ & $\begin{array}{l}\text { Hyaline, } \\
\text { Septate }\end{array}$ & Forked \\
\hline $\begin{array}{l}\text { Water } \\
\text { melon }\end{array}$ & $\begin{array}{c}\text { Erysiphe } \\
\text { cichoracearum }\end{array}$ & 30.818 & 28.218 & $\begin{array}{l}\text { Ellipsoid to } \\
\text { ovoid }\end{array}$ & $\begin{array}{l}\text { Hyaline, } \\
\text { Septate }\end{array}$ & Lobed \\
\hline
\end{tabular}

*Values are mean of ten conidia
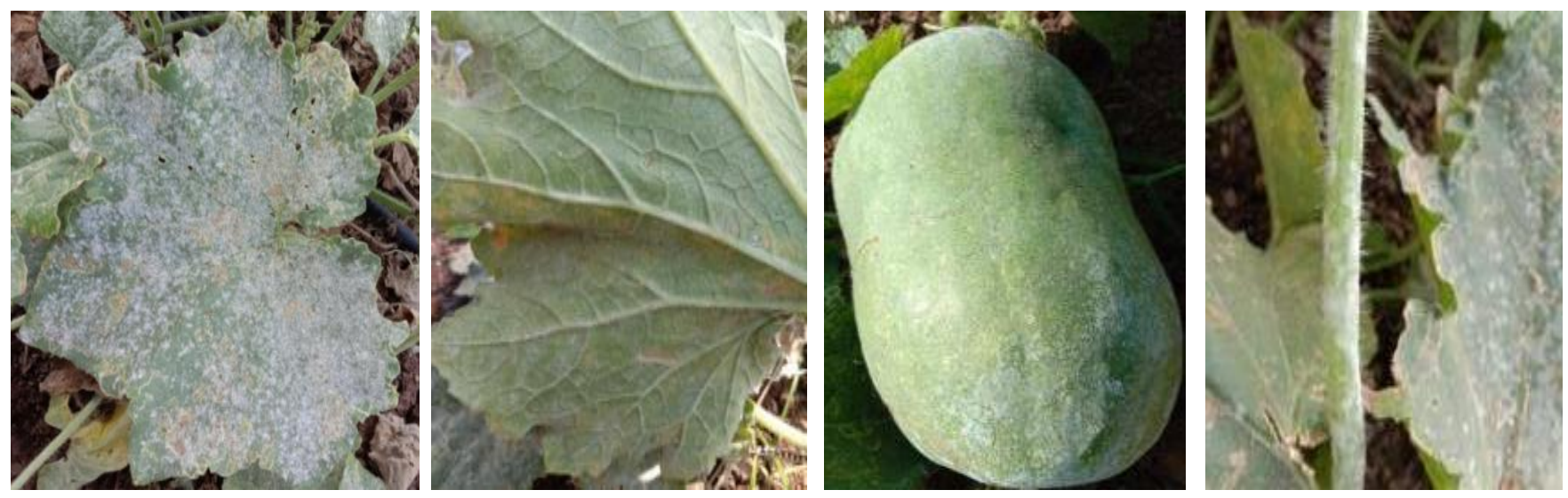

Figure.1 Symptoms of powdery mildew on cucurbits observed under field conditions

A. Abundant powdery patches at severe stage of infection

B. Powdery growth on rear side of the leaf

C. Powdery growth on petiole

D. Powdery growth on fruit (ash gourd) 

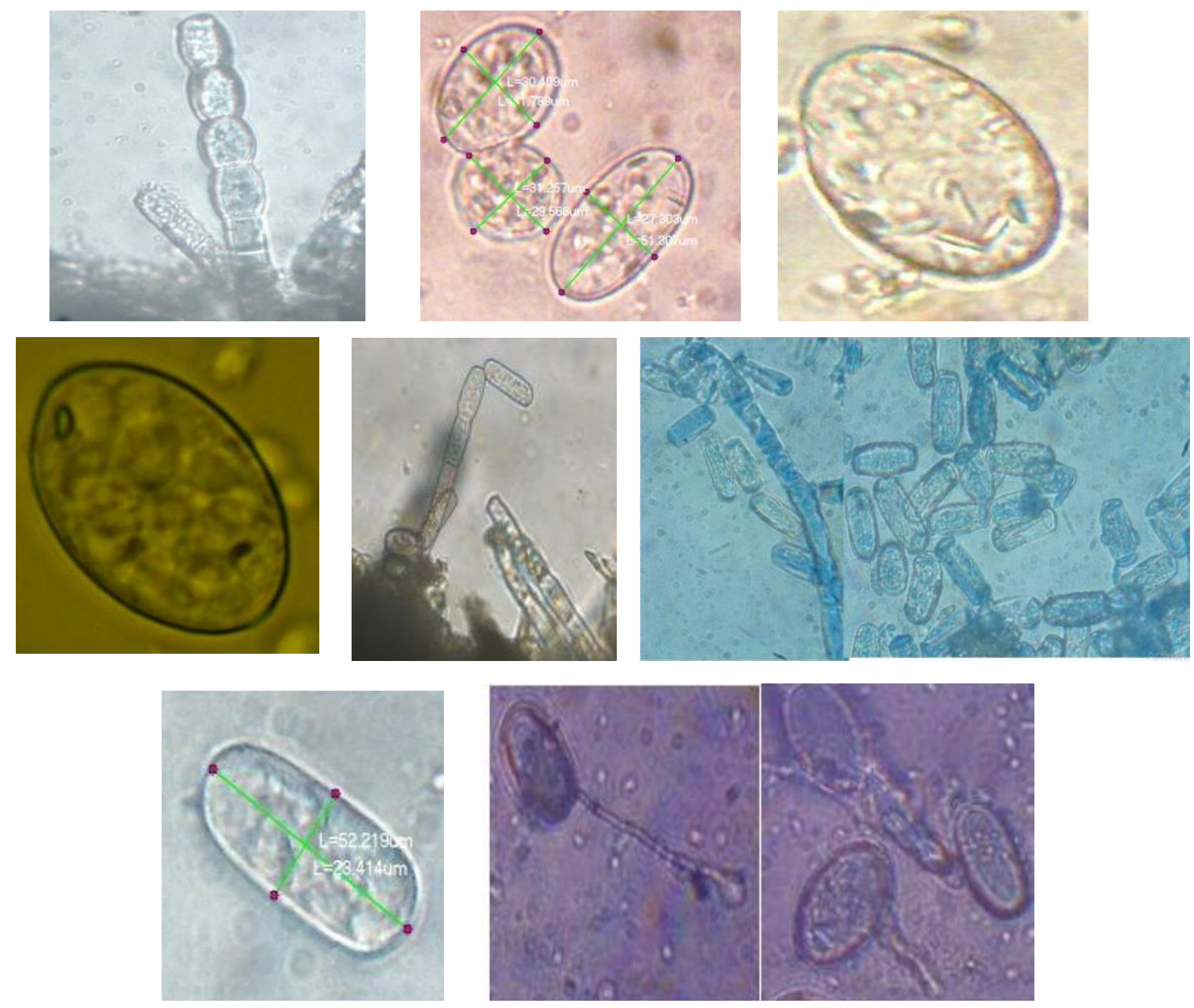

Fig.2 Microscopic studies of powdery mildew causal agents
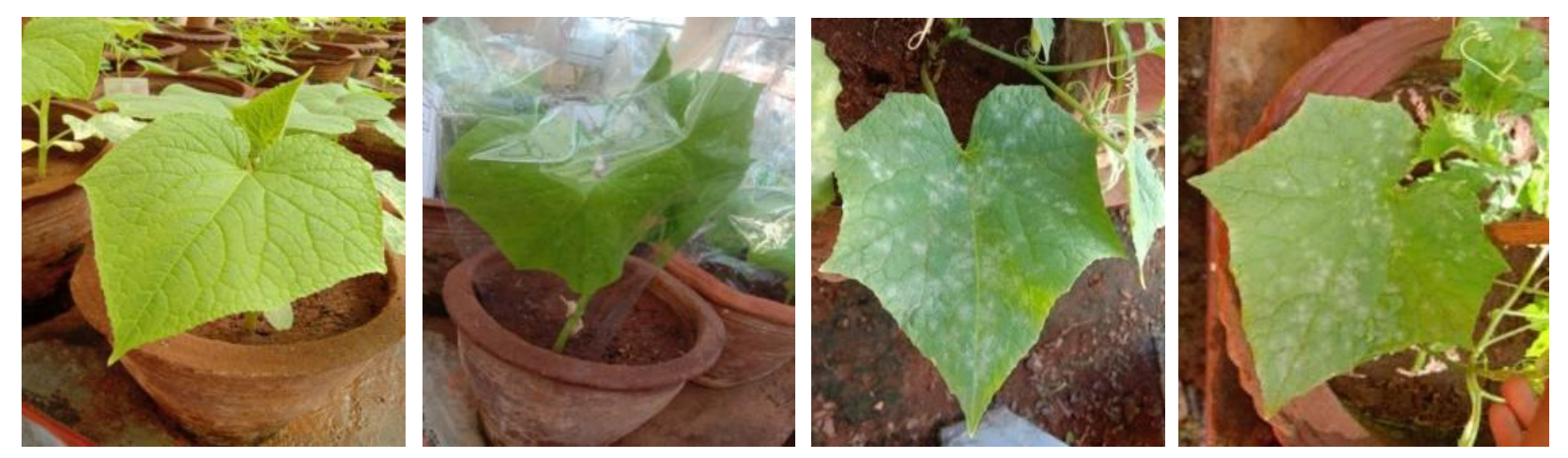

Fig.3 Pathogenecity assay for Podosphaera xanthii 

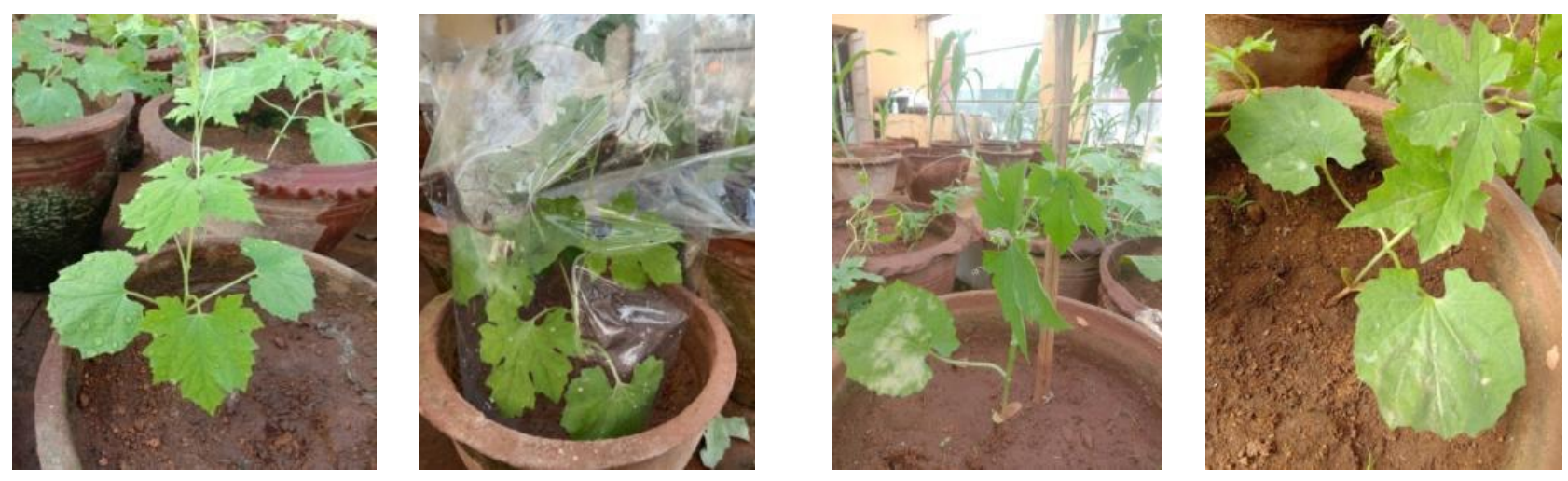

Fig.4 Pathogenecity assay for Erysiphe cichoracearum

Simple apical germ tube with lobed appresoria of E. cichoracearum I. Tubular germ tube of P.xanthii. A. Uninoculated control plant B. Inoculated plant covered with polythene covering $\mathrm{C}$. Initial symptoms seen on $4^{\text {th }}$ day of inoculation $D$. The powdery mildew symptoms on $10^{\text {th }}$ day of inoculation

A. Uninoculated control plant B. Inoculated with powdery mildew conidia covered with polythene cover C. Initial symptom development after $5^{\text {th }}$ day of inoculation $D$. The symptom at $10^{\text {th }}$ day of inoculation.

This preliminary study of the morphological and microscopic characteristics of the cucurbit powdery mildew causal agents paves the way for successful disease management. Further, it has to subjected to scanning electron microscopic studies for better understanding.

\section{Acknowledgement}

Authors would like to acknowledge the support provided by the Department of Plant Pathology, Tamil Nadu Agricultural University, Coimbatore and also extends our sincere thanks to the department for providing infrastructure facilities (Biocontrol lab, FIST lab).

\section{References}

Aguiar, B.D.M., Vida, J.B., Tessmann, D.J., Oliveira, R.R.D., Aguiar, R.L. and Alves. T.C.A.2012. Fungal species that cause powdery mildew in greenhousegrown cucumber and melon in Parana State, Brazil. Acta Scientiarum. Agronomy.,34(3) : 247-252.

Bademiyya, S.I. and Ashtaputre, S.A. 2019. Morphological Variability of Conidia of Leveillula taurica (Lev.) Arn Causing Chilli Powdery Mildew. Int. J. Curr. Microbiol. App. Sci., 8(4) :2965-2968.

Braun, U., Cook, R.T.A., Inman, A.J. and Shin. H.D. 2002. The taxonomy of the powdery mildew fungi. The powdery mildews: a comprehensive treatise.,1355.

Cohen, R., Burger, Y., Shraiber, S., Elkind, Y. And Levin. E.1996. Influence of the genetic background and environmental conditions on powdery mildew of melons. Phytoparasitica.,24:162.

Cohen, R., Shtienberg, D. and Edelstein. M. 1996. Suppression of powdery mildew (Sphaerotheca fuliginea) in cucumber by the detergent Zohar LQ-215. European journal of plant pathology., 102 (1): 69-75.

El-Naggar, M.A., El-Deeb, H.M. and Ragab. S.S. 2012. Applied approach for 
controlling powdery mildew disease of cucumber under plastic houses. Pakistan Journal of Agriculture: Agricultural Engineering Veterinary Sciences (Pakistan).

Frolov, V.V. 1996. Species structure of fungi powdery mildew fungi in melon in Kherson. In Proceedings of the international conference "Selection and technology: cucurbits production., 114117.

Gupta, M.K. and Sharma, G.K. 2012. Studies on the dynamics of powdery mildews on cucurbits in Haryana, India. Indian Journal of Scientific Research., 3(1) :101-106.

Jamadar, M.M. and Desai. S.A. 1997. Bioefficacy of dimethomorph against downy mildew of grapevine. $A d v$. Agric. Res. India, 4 : 81-85.

Khan, M.W. and Khan, A.M. 1970. Studies on the Cucurbit powdery mildew. I. Perithecial production in Cucurbit powdery mildew in northern India. Indian

Phytopathology., 23(3):497-502.

Kristkova, E. And Lebeda. A. 2000. Powdery mildew field infection on leaves and stems of Cucurbita pepo accessions. In VII Eucarpia Meeting on Cucurbit Genetics and Breeding 510 : 61-66.

Lebeda, A., McGrath, M.T. and Sedlakova. B. 2010. Fungicide resistance in cucurbit powdery mildew fungi. Fungicides., 11: 221-246.

Lovepreet Kaur. 2019. Morphological Characterization and Pathogenicity of Oidium mangiferae on Mango. Int.J.Curr.Microbiol.App.Sci.8(5): 1297-1300.

McCreight, J.D. 2004. Notes on the Change of the Causal Species of the Cucurbit Powdery Mildew in the US. REPORTCUCURBIT GENETICS COOPERATIVE, 27:8.

McKinney, H.H. 1923. A new system of grading plant diseases. J. Agric. Res., 26(2):195-218.

Parameshwar Naik, H. and Shripad Kulkarni. 2018. Survey of powdery mildew in major cucumber growing areas of Northern Karnataka Int.J.Curr.Microbiol.App.Sci.,7(4): 3015-3024.

Parthasarathy, S., Muthamilan, M., Harish, S., Alice, D. and Raguchander, T. 2017. Natural Incidence and Genetic Variability of Erysiphe pisi, the Causal Agent of Powdery Mildew on Peas in the Nilgiris District, Tamil Nadu, India. Current Journal of Applied Science and Technology, 1-11.

Parthasarathy, S., Muthamilan, M., Harish, S., Alice, D. and Raguchander, T. 2017. Studies on Morphological Characterization of Erysiphe pisi Causing Powdery Mildew of Pisum sativum by Environmental Scanning Electron Microscope. Int. J. Pure App. Biosci., 5(6) :1348-1355.

PEREZ-GARCIA, A.L.E.J.A.N.D.R.O., Romero, D., FERNANDEZ ORTUÑO, D.O.L.O.R.E.S., LOPEZRUIZ, F.R.A.N.C.I.S.C.O., De Vicente, A. and Tores. J.A. 2009. The powdery mildew fungus Podosphaera fusca (synonym Podosphaera xanthii), a constant threat to cucurbits. Molecular plant pathology.,10(2) :153-160.

Rajalakshmi, J., Parthasarathy, S., Narayanan, P. and Prakasam.V. 2016. Survey of the incidence and severity of Bhendi (Abelmoschus esculentus (L.) Moench.) and Peas (Pisum sativum L.) Powdery Mildew diseases in Tamil Nadu, India. Advances in Life Science., 5(3):808-814.

Rankovic, B. 2003. Powdery mildew fungi (order Erysiphales) on plants in Montenegro (Chernogoria). Mikologiya i Fitopatologiya., 37(3):42-52.

Rur, M., Ramert, B., Hokeberg, M., Vetukuri, 
R.R., Grenville-Briggs, L. And Liljeroth.E.2018. Screening of alternative products for integrated pest management of cucurbit powdery mildew in Sweden. European journal of plant pathology.,150(1):127-138.

Vakalounakis, D.J., Klironomou, E. And Papadakis. A.1994. Species spectrum, host range and distribution of powdery mildews on Cucurbitaceae in Crete. Plant Pathology.,43(5) :813-818. Wang, X.Z., Xu, B.Y., Ping, W., Luan, F.S., Ma, H.Y. and Ma. Y.Y. 2013. Identification of powdery mildew pathogen and ribosomal DNA-ITS sequence analysis on melon. Journal of Northeast Agricultural University (English Edition)., 20(4):10-18.

\section{How to cite this article:}

Priyanka. S., L. Rajendran, R. Anandham and Raguchander. T. 2020. Characterization of Cucurbit Powdery Mildews by Morphological and Microscopic Studies. Int.J.Curr.Microbiol.App.Sci. 9(07): 472-481. doi: https://doi.org/10.20546/ijcmas.2020.907.052 